\title{
Effects of Succession Planning Programs on Staff Retention
}

\author{
Stephen Nyikuli Eshiteti \\ Department of Business Management \\ Masinde Muliro University of Science and Technology, Kenya \\ Ochieng Okaka \\ Department of Business Management, Masinde Muliro \\ University of Science and Technology, Kenya \\ Dr. Samuel N. Maragia \\ Department of Educational Psychology \\ Masinde Muliro University of Science and Technology, Kenya

\section{Odhiambo Odera (Corresponding author)} \\ University of Southern Queensland, Australia and Masinde Muliro \\ University of Science and Technology, Kenya Email: oodera@yahoo.com

\section{Emmanuel Kayode Akerele} \\ Department of Accounting, Faculty of Business Administration, \\ University of Lagos, Nigeria
}

Doi:10.5901/mjss.2013.v4n6p157

\begin{abstract}
Learning about factors that affect staff retention and ways of improving it, can help firms avoid the inconvenience of high attrition. Thus, the purpose of this study was to establish the effects of succession planning programs on staff retention in the sugar companies of Western Province, Kenya. Management staff members were purposively selected, stratified and simple randomly sampled. Data collection was done by use of questionnaires. Descriptive and inferential statistical methods were employed to analyze the data. Findings of the study indicate that more employees had high job satisfaction because of going through the succession planning process with the hope of being next in line of management. This had a positive effect on the retention of staff in the sugar firms under study.
\end{abstract}

Keywords: Succession planning, staff retention, job satisfaction

\section{Introduction}

Staff turnover in the changing and highly competitive business environment is on the increase in most organizations in the world today (Sullivan, 2008). As a result, there are changes in workforce demographics, global competition, mergers, acquisition volumes, and technology that call for the act of developing a pool of talent to take up leadership responsibilities and push the businesses to the next level. Although some managers feel that the problem of high attrition rate is insignificant because of the high rate of unemployment, it is however threatening to add another impediment to the growth and survival of many firms (Pattanayak, 2005). In Kenya, 47\% of firms that undergo shrinking or close up do so because of lack of competent managers that are able to motivate employees to stay longer (Nzuve, 2008). On the contrary, employee turnover can be quite expensive. Beside recruitment and selection expenses, the cost associated with creating new employee records in the human resource department, establishing payroll records in the accounting section and the provision of safety equipment are costs incurred when employees leave (Woods, 1997).

Accordingly, with the rampant incidences of changing jobs, aging on part of the workforce, organizational flattening 
and downsizing, it is necessary that organizations forecast their internal personnel changes, identify possible backup candidates, keep track of attrition (resignation, retirements, etc.) and retain the very best of their employees. Consistent with this, some sugar firms in Kenya engage in management training programs in order to develop a pool of talent for possible successions. Many organizations do not have formal preparation programs to create "a feeder system" of high potential employees into management positions. Without any kind of feeder system like succession planning, some firms struggle to fill vacancies particularly of the management level. This situation tends to lead into deep dissatisfaction among employees and the result is decreased performance and retention rates among high performers. However, in recognition of the detrimental effects of turnover, research on the determinants of turnover and retention strategies is growing (Jiang \& Klein, 2002). Not much known about employee retention in the context of succession planning programs effect in the sugar companies in Kenya. Therefore, this study attempted to establish the effects of having succession planning programs on staff retention in the sugar firms of Western Province, Kenya.

\section{Literature Review}

Noe et al (2000) define succession planning as a process of identifying and preparing suitable high potential employees to replace key players within the organization as their terms expire. William et al (1996) assert that regardless of the expansion or contraction of the total workforce in the organizations, the need for good managers is critical and continuous. They further stated that the availability of the right number, right kind of management staff at the right time and in the right positions is imperative. A sudden vacancy can lead to confusion and loss of efficiency as the search for a replacement is conducted. The absence or loss of an employee could cause an inconvenience that could be avoided with some anticipation to serious succession development. Therefore, planning on how one's shoe is going to be filled when he is no longer there and even planning for knowledge coverage when one is ill or vacationing simply makes good business sense. For professionally run corporations, the single most important reason for having a sound succession plan is usually better retention because of growth opportunities and job satisfaction among employees.

Therefore, for a company that wishes to enhance its performance, to allow its high potential employees turnover is not an option, but to rather arrange them in systematic successions, by enabling them to effectively perform roles traditionally reserved for managers. It also helps employees prepare for changes in their current jobs that may result from new technology, work designs or new product markets. Thus, succession planning is a necessary component of a company's effort to improve quality, meet challenges of global competition, social change and incorporate technology advances. Ruthwell (2005) examined succession planning as a staffing responsibility that relates to promotions, terminations and retirement. In addition, succession planning has a direct impact on reducing staff turnover.

\subsection{Job Satisfaction and Staff Retention}

Ellsworth \& Szuch (2008) analyze factors by agency in order to pinpoint possible differences in job satisfaction and employees intent to leave. However, because demographic differences such as gender and age could have varying effects on job satisfaction and job turnover, it was also important to analyze responses by these categories in order to understand workplace dynamics. Job turnover has a number of negative effects on a workplace, including increased costs to fill open positions and lower employee morale. Ellsworth \& Szuch (2008) identified differences in selected factors that may influence employees stated intent to change jobs by age and gender.

According to Ishigaki (2004), employees are more satisfied when they feel they are rewarded fairly for the work they do and that the rewards are for genuine contributions to the organization and consistent with the reward policies. The reward may include a variety of benefits and perquisites other than monetary gains. Employees with higher job satisfaction are important, since they believe that the organization has a tremendous future and in the end, it would care about the quality of their work. Hence, they are more committed to the organization, have higher retention rates and may tend to have higher productivity. Committed employees are more likely to perform beyond the call of duty to meet customers' needs and are highly motivated to work to the best of their ability. Committed employees remain in employment of the company longer, resist competitive job offers, do not actively look for other employment and recommend the company to others as a good place to work. Recent studies have shown that managers are able to reduce unwarranted employee turnover, because the most important factors driving employee satisfaction and commitment are largely within the direct control of the manager. These may include providing recognition, regular feedback and ensuring fair compensation reflecting an employee's contributions and value to the organization (Insight link Communication, 2004). 
Whilst it is easy to imagine the relationship between job satisfaction and labour turnover, the relationship between job satisfaction and motivation is more complex and in some respects, rather surprising. One would expect labour turnover to decrease as job satisfaction and motivation increases. However, what is the direction of influence between job satisfaction among employees and motivation? If an employee is more satisfied, is he also more motivated or does motivation cause job satisfaction? To understand the relationship between these three concepts, it is necessary to start with the behavioral aspect- that of people leaving. Whether they leave or stay does act as an indicator of job satisfaction, in this case, through employee development practices such as succession programs (Riley \& Wrench, 2000). Job satisfaction is a key pivotal concept in this because it has been shown that labour turnover is dependent upon it.

\subsection{Effective Staff Retention through Succession Planning}

Turnover is very costly to an employer in terms of monetary implications, its effect on employee morale and customer satisfaction. Some studies have estimated that the cost of replacing an employee can be enormous due to advertising and recruiting, lost productivity, and time spent on training a new employee (Abbasi \& Hollman, 2000). It takes time for new employees to gain knowledge about systems and procedures. In addition, the public may not obtain the level of benefits or care to which they are entitled and receiving these benefits may take more time than it would, if the employee had more experience. However, Milkovich \& Boundreau (1988) assumed that workforce retention could be a highly charged issue, because it literally affects the livelihood of an employee. They also asserted that it might do very little good to invest in valid selection, improved compensation or extra training, if an organization cannot retain its employees effectively. Hence, the need for a succession plan that would not only focus on those who might be candidates for current positions but also, attempt to plan for possible changes in those positions as well as the promotion and development needs of sub-ordinates.

Managing workforce retention requires paying attention to efficiency and equity. Whether staff turnover occurs due to employee resignations, retirements, layoffs or discharge, administering the succession process often may incur the organization substantial costs. Milkovich \& Boundreau (1988) is of the opinion that successions through internal staffing works, when it puts the right quantity and quality of current employees in the right employment opportunities at a minimum cost. Thus, managers should argue that turnover, especially through resignations, should be reduced and employees encouraged to keep working with the organization through interventions such as succession programs. On productivity, benefits are substantial if employers manage turnover so that the most valuable performers are retained (Bottomley, 1983). However, the magnitude of the effects depends on the quality and quantity of the retained workforce. It anticipates critical shortages due to attrition to provide for succession development and ensure that replacements exist among the retained workforce. Equally, employee successions usually affect the equity perceptions of several company constituencies (Nzuve, 2008). Accordingly, it is not enough for management policies to ensure high organizational productivity. Thus, employees equity perceptions are shaped by the perceived fairness and consistency in promotions and replacements.

\section{Research Methodology}

A descriptive survey research design was adopted. The study was conducted in sugar companies of Western Province, Kenya namely: Mumias Sugar Company (MSC), Nzoia Sugar Company (NSC) and West Kenya Sugar Company (WSC). Study respondents consisted of management staff members of the three sugar companies. A semi-structured questionnaire was used constituting of a five - point likert scale. It was administered to 90 respondents from section heads, superintendent, and supervisors' categories in MSC, NSC and WSC. Descriptive statistics were used to analyze the data.

\subsection{Sampling Procedure}

Purposive sampling was employed to obtain the three sugar firms within the province. Six departments that are common across the three companies were sampled (see Table 1). 
Table 1: Sample size per department

\begin{tabular}{lcc}
\hline Department/Section & Frequency & Percentage \\
\hline Human resource & 20 & 22.2 \\
Agriculture & 35 & 38.9 \\
Factory operations/Engineering & 12 & 13.3 \\
Finance & 10 & 11.1 \\
Sales and Marketing & 8 & 8.9 \\
Information Technology & 5 & 5.6 \\
\hline Total & 90 & 100.0 \\
\hline
\end{tabular}

Source: Research Data,2012

Stratified sampling was then employed in order to achieve desired representation from the various sub-groups in the population. Companies were sub-divided into 3 strata sizes of top management- section executives, middle level managers - superintendents and supervisors (see Table 2).

Table 2; Sample size distribution per strata per company

\begin{tabular}{lcccc}
\hline Job Category & MSC & NSC & WSC & Total \\
\hline Supervisors & 23 & 14 & 10 & 47 \\
Superintendents & 17 & 7 & 5 & 29 \\
Section Heads & 7 & 4 & 3 & 14 \\
\hline Total & $\mathbf{4 7}$ & $\mathbf{2 5}$ & $\mathbf{1 8}$ & $\mathbf{9 0}$ \\
\hline
\end{tabular}

Source: Research Data, 2012

Simple random sampling was then used to select respondents from each stratum. Supervisory level of management category had the largest number of respondents followed by superintendents while the section executives were the least in number. The largest number of respondents was drawn from MSC, followed by NSC and then WSC.

\section{Data Analysis and Findings}

\subsection{Availability of Succession Planning Programs}

Table 3: Reasons for staff retention

\begin{tabular}{lccc}
\hline Reason & MSC & NSC & WSC \\
\hline Training and development & $66.7 \%$ & $33.3 \%$ & $27.3 \%$ \\
Diversification and expansion & $13.3 \%$ & $13.3 \%$ & $18.1 \%$ \\
Compansation level & $10.0 \%$ & $20.0 \%$ & $9.1 \%$ \\
Staff welfare & $3.3 \%$ & $6.7 \%$ & $0.0 \%$ \\
Lack of employment opportunities elsewhere & $6.7 \%$ & $26.7 \%$ & $45.5 \%$ \\
\hline Total & 100.0 & 100.0 & 100.0 \\
\hline
\end{tabular}

Source: Research Data, 2012)

According to Table 3, MSC had $66.7 \%$, NSC $33.3 \%$ and WSC $27.3 \%$ of their respondents mentioning Training and Development approaches as the main activities being carried out by their companies to retain them. In general, for MSC and NSC $13.3 \%$ of their respondents felt that diversification and expansion strategy taken by their respective companies was an important contributor to their continued stay within those firms. Compensation level was the number one cause for continuos stay at their present companies according to $20 \%$ of NSC respondents. $45.5 \%$ of the WSC respondents stated that lack of employment opportunities elsewhere contributed a bigger role on staff retention in the sugar firms under research.

\subsection{Job Behaviour Change and Succession Training}

Results indicate the respondents' perceptions on the behavior change of their immediate supervisors after undergoing a T\&D program meant to enhance their management skills. 
Table 4: Succession Programs Influence on Job behavior change of Supervisor

\begin{tabular}{lc}
\hline Supervisors job demographics & Mean value \\
\hline Commitment to work & 4.50 \\
Level of supervision & 4.375 \\
Communication to staff & 4.35 \\
Delegation of work & 4.227 \\
Making of decisions & 4.225 \\
Motivating staff & 4.10 \\
Grievance handling & 4.00 \\
\hline Mean value of the total means & 4.261 \\
\hline
\end{tabular}

Source :Research Data,2012

Table 4 indicates that the mean scores show that a majority of respondents (mean=4.261) have a positive attitude towards their bosses ability to perform on different fronts as listed due to having gone through succession planning programs. When asked to rank the most important areas of improvement as a result of the programs, respondents indicated the supervisors commitment to work (mean=4.5), quality of supervision (mean=4.375), communication to the staff (mean=4.35), delegation of work (mean=4.227) and decision-making (mean=4.225). They further indicated the supervisors additional improvement in areas such as motivating staff (mean=4.1) and grievance handling techniques (mean=4.0).

\subsection{Perception of Employees on Organizations Staff Retention}

The study also sought to assess the perceptions of employees on the available succession planning programs' influence on staff retention in their respective companies. Results obtained were established on a five-point scale measuring the various retention variables in relation to succession planning programs. In Table 5, SD, D, N, A, and SA represented Strongly Disagree, Disagree, Neutral, Agree and Strongly Agree. Results were analyzed and presented by means. A mean value below 2.5 shows that the respondents do not agree with the assertion on the likert scale as shown in Table 5

Table 5: Influence of Succession Planning Programs on Staff Retention

\begin{tabular}{lcccccc}
\hline Question items & SD & D & N & A & SA & Means \\
\hline Like to stay longer & 2 & 2 & 3 & 76 & 85 & 4.20 \\
Sense of Belonging over time & 0 & 6 & 9 & 84 & 65 & 4.10 \\
Willing to put in great deal of effort & 0 & 0 & 9 & 60 & 110 & 4.475 \\
One grows fond of org over years & 0 & 4 & 12 & 76 & 60 & 3.80 \\
Learning opportunity improved retention & 1 & 16 & 27 & 40 & 60 & 3.60 \\
Top mgmt. sees it HRs of great value & 2 & 6 & 27 & 60 & 55 & 3.75 \\
Managers are easy and friendly & 0 & 8 & 15 & 80 & 55 & 3.95 \\
Major satisfaction is in my job & 0 & 6 & 6 & 72 & 85 & 4.225 \\
Sense of being in mgmt. encourages me to stay & 2 & 6 & 24 & 56 & 65 & 3.825 \\
Absenteeism \& lateness is not a problem & 7 & 20 & 9 & 48 & 40 & 3.1 \\
Org is better place to work and live & 2 & 4 & 12 & 44 & 110 & 4.30 \\
Employees not willing to leave & 12 & 16 & 24 & 24 & 30 & 2.575 \\
\hline Average means & & & & & & 3.825 \\
\hline
\end{tabular}

Source: Research Data, 2012

Table 5 also suggests that an employee's stage in life determines one's stability in a job. It's possibly in line with this observation that a majority of respondents (mean=3.80) were reported to be of the view that one grows fond of their organization on the basis of seniority (the length of service that an employee has given to the organization in question). Thus, a majority of those who disagreed were young employees between 25-34 years of age, whereas a majority of those who agreed with the statement were older and married employees who had been with the organization for a longer period. Majority of respondents (mean=4.10) had a strong feeling that the longer they stayed the more they felt that they belong, consequently this group of employees reported to have grown fond of their organizations over the years $($ mean=3.80). The results revealed that a majority of respondents (mean=2.575) were not willing to leave the organization. 
Table 6: Organization based Factors

\begin{tabular}{lc}
\hline Question item & Ranking means \\
\hline My organization is a good place to work and live & 4.30 \\
I would like to stay longer in this firm & 4.20 \\
One feels a sense of belonging over time & 4.10 \\
A sense of being in management enhances my stay & 3.83 \\
One grows fond of this organization over the years & 3.80 \\
Many employees are willing to leave the organization & 2.58 \\
\hline Mean value of the Total means & 3.80 \\
\hline
\end{tabular}

Source: Research Data, 2012

In Table 6, the majority of respondents were of the opinion that they would like to stay longer in their current organizations (mean=4.20), since their respective organizations are better places to work and live (mean=4.30). This high rating could be attributed to the already discussed factors that include job satisfaction characteristics.

Therefore, this study established that the likelihood to stay was low for those who had responded to having a low level of commitment in their own jobs, neutral to their sense of responsibility, and authority to perform their work well. Those who rated highly in job dissatisfaction (those who indicated that they were not satisfied with their financial status, opportunities for advancement, and sense of responsibility, etc.) were the same respondents who indicated that they did not feel that they belong and that their top managers did not see them as being of considerable importance.

\section{Conclusions}

The findings of the study indicate that the three sugar manufacturing companies in Western Province of Kenya engage in formalized succession planning in order to offer the knowledge to help high potential employees fit into management positions. Therefore, succession planning programs emerged as a strong factor influencing staff retention. The influence was mainly through provision of employee growth opportunities and job satisfaction. This was enabled through programs such as job rotation, mentoring, coaching and other formal training programs like action learning. The process provides some guidelines to assist managers understand how to reduce employee turnover, increase job satisfaction and employees professional and personal growth. Thus, organizations investment in their staff and improvement contributes to a pool of talent, which benefits the whole organization through retention.

\section{References}

Abbasi, S.M. \& Hollman, K.W. (2000) Turnover: The real bottom line Public Personnel Management, 29(3), 333-343

Bottomley, M. (1983) Personnel Management Pitman Publishing Company, London

Ellsworth and Szuch (Eds.) (2008) Succession Planning Report: A survey of employees. Retrieved, from http://doe.state.wy.us/LMI/SPR_08/retire.htm

Insightlink Communication, (2004). The State of Employee Satisfaction. http://www.insightlink.com/employee satisfaction.html Ishigaki, D. (2004) Effective Management through Measurement. http://www.ibm.com/developerworks/rational/library/4786.html Jiang, J. and Klein, G. (2002) Strategic Information and Strategic Decision Making: The EIS/CEO Interface in Smaller Manufacturing Companies Information \& Management, 40 1-9 (SSCI, IF 2.119)

Milkovich, T. and Boudreau, J. (1988) Personnel /Human Resource Management: A Diagnostic Approach 5th Edition Homewood Illinois

Noe, A., Houston, G., Hollenbeck, R., Gerhart, and Wright, M. (2000) Human Resource Management Gaining a competitive Advantage 3rd Edition. McGraw-Hill companies Inc. Boston.

Nzuve, S. (2008) Management of Human Resources: A Kenya perspective Revised edition, Basic modern management consultants, Nairobi

Pattanayak, B. (2005) Human Resource Management 3rd Edition Prentice Hall India New Delhi

Riley, M. and Wrench (2000) Managing people: professional hospitality guide Second edition, a Division of Reed Educational and Professional Publishing Ltd, Great Britain

Ruthwell, W. (2005) Effective Succession Planning for Retention A Research Project, Ontario Canada

William, B., Weather, R. and Keith, D. (1996) Human Resource and Personnel Management 5th Edition, McGraw-Hill series in Management, New York

Woods, R. (1997) Managing Hospitality Human Resource 2nd Edition Educational Institute, American Hotel\& Motel Association 